\title{
Tissue conditioning - strategies to improve perfusion and reduce ischemia - reperfusion injury
}

\author{
Sabrina Krauss ${ }^{1}$, Jens Rothenberger ${ }^{1}$, Johannes Mayer ${ }^{1}$, Alexander Sogorski ${ }^{2}$, Manuel Held ${ }^{1}$, Theodora \\ Wahler $^{1}$, Adrien Daigeler ${ }^{1}$, Jonas Kolbenschlag ${ }^{1}$ \\ 'Department of Hand, Plastic, Reconstructive and Burn Surgery, BG Trauma Center Tuebingen, Eberhard Karl University Tuebingen, \\ Tuebingen 72076, Germany. \\ 2Department of Plastic Surgery, Burn Center, BG University Hospital Bergmannsheil, Ruhr-University Bochum, Bochum 44789, Germany.
}

Correspondence to: Dr. Sabrina Krauss, Department of Hand, Plastic, Reconstructive and Burn Surgery, BG Trauma Center Tuebingen, Eberhard Karl University Tuebingen, Tuebingen 72076, Germany. E-mail: SabrinaKrauss@gmx.net

How to cite this article: Krauss S, Rothenberger J, Mayer J, Sogorski A, Held M, Wahler T, Daigeler A, Kolbenschlag J. Tissue conditioning - strategies to improve perfusion and reduce ischemia - reperfusion injury. Plast Aesthet Res 2018;5:39.

http://dx.doi.org/10.20517/2347-9264.2018.41

Received: 4 Jun 2018 First Decision: 13 Aug 2018 Revised: 10 Sep 2018 Accepted: 10 Sep 2018 Published: 29 Sep 2018

Science Editor: Raymund Engelbert Horch Copy Editor: Yuan-Li Wang Production Editor: Zhong-Yu Guo

\begin{abstract}
Ischemia as well as ischemia-reperfusion injury (IRI) can cause serious tissue damage and therefore is a feared complication in reconstructive surgery. This is the reason why researchers around the world invest their efforts to improve tissue viability after ischemic events. Tissue conditioning offers a broad scope of different techniques which can be applied pre-, peri- or postoperatively to adapt the affected tissue to the subsequent stress during and after ischemia to prevent or minimize IRI. The different ways of tissue conditioning in flap surgery include surgical delay, ischemic conditioning, remote ischemic conditioning as well as thermic preconditioning and other techniques, using growth factors, pharmaceutical agents, extracorporeal shock waves as well as stemm cells. Therefore, we want to shed some light on the effects of ischemia and ischemia-reperfusion injury and further illustrate the different strategies of tissue conditioning with special concern to flap surgery but also regarding wound healing in general.
\end{abstract}

Keywords: Tissue conditioning, ischemia, ischemia-reperfusion injury, reconstructive surgery, flap surgery, wound healing

\section{INTRODUCTION}

Cell damage caused by ischemia affects almost all clinical disciplines, seen in daily clinical routine for example as heart attacks, strokes, in organ transplantations as well as in reconstructive surgical procedures such as flap surgery ${ }^{[1]}$. Ischemia as well as ischemia-reperfusion injury (IRI) represent a formidable challenge

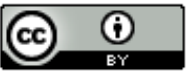

(C) The Author(s) 2018. Open Access This article is licensed under a Creative Commons Attribution 4.0 International License (https://creativecommons.org/licenses/by/4.0/), which permits unrestricted use, sharing, adaptation, distribution and reproduction in any medium or format, for any purpose, even commercially, as long as you give appropriate credit to the original author(s) and the source, provide a link to the Creative Commons license, and indicate if changes were made.

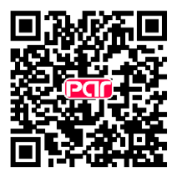


in the transplantation of solid organs, in vascularized tissue allotransplantations (VCA) such as hand or face transplantations and in free flaps. In VCA for example, cold ischemia time is $6 \mathrm{~h}$ on average ${ }^{[2,3]}$. The importance of ischemia reperfusion-injury in tissue transplantation is clearly illustrated by its impact on early graft function as well as long-term outcomes ${ }^{[4]}$.

Insufficient tissue perfusion plays an important role in chronic wounds as well. Tissue hypoxia is responsible for a lack of energy metabolism, cell proliferation, angiogenesis, cytokine release as well as enzyme activity and therefore leading to an impairment of the tissue repair process ${ }^{[5-7]}$. Common causes for tissue hypoxia in chronic wounds are vascular alterations, oedema and fibrosis resulting in reduced oxygen partial pressure $\left(\mathrm{pO}_{2}\right)^{[7]}$. An interesting discovery is that $\mathrm{pO}_{2}$ in chronic wounds is $5-20 \mathrm{mmHg}$ compared to $30-50 \mathrm{mmHg}$ in control tissue ${ }^{[8]}$. In plastic surgery, tissue perfusion is of special concern due to the field of reconstructive surgery, where temporary tissue ischemia in free flaps as well as reduced perfusion in pedicled flaps has to be accepted to be able to treat tissue defects. In skilled and experienced hands, total flap loss is reported to occur in $1 \%-7 \%$ of cases, depending on recipient site and cause of the tissue defect ${ }^{[9-12]}$. But the rate of partial flap necrosis is much higher, with rates of 7\%-20\% in free flaps and even $20 \%-33 \%$ in pedicled flaps ${ }^{[1-16]}$. Partial flap necrosis often requires further operations, thus putting a significant burden on the affected patient as well as the healthcare system.

All those examples illustrate the significance of tissue blood supply and the need for methods to improve it. Or, as Gillies ${ }^{[17]}$ once put it, "plastic surgery is the constant battle between beauty and blood supply".

In this unsystematic review, we want to shed some light on the effects of ischemia and IRI on the affected tissue and illustrate different strategies of tissue conditioning focusing on its use in flap surgery.

\section{Pathomechanisms of ischemia and IRI}

The persistence of insufficient tissue perfusion or total ischemia results in a loss of oxygen supply and therefore causes a change of cell metabolism as an adjustment to the lack of the aerobic pathway in the respiratory chain. This leads to an accumulation of metabolites as well as radicals and causes cell death ${ }^{[18,19]}$. Ironically, restauration of perfusion causes additional tissue damage due to inflammatory mechanisms caused by the release of oxygen compounds. Those lead to an activation of neutrophils and a consecutive adhesion between granulocytes and endothelial cells causing segmental vessel occlusion in postcapillary venules, transendothelial leukocyte migration and the release of tissue-damaging enzymes. This pathomechanism is referred to as the IRI $^{[20-25]}$. With regard to flap surgery, flap survival is mainly depending on the integrity of the vascular pedicle and its "macrovascular" perfusion ${ }^{[26]}$. IRI on the other hand affects the microcirculation of the entire flap due to the inflammatory process and the increase in oxygen free radicals in the early stages of reperfusion ${ }^{[27]}$. Therefore, partial flap necrosis is often caused by an insufficient microcirculation mainly in the distal parts of the flap.

Total flap necrosis on the other hand is most often caused by thrombosis of the pedicle. Timely revision of the anastomosis is paramount to reestablish blood flow to the flap. However, such events can lead to an increase IRI which in term can lead to intravascular hemoconcentration, endothelial swelling, interstitial edema formation as well as inflammatory processes due to the reperfusion injury. In its highest degree, IRI can lead to a no-reflow phenomenon which also leads to complete flap loss ${ }^{[28-30]}$.

\section{Tissue conditioning}

There are different means of pre- or peri- and postoperative techniques to adapt the tissue to the subsequent stress during and after ischemia to prevent or minimize IRI [Table 1]. 
Table 1. Different ways of tissue conditioning

\begin{tabular}{l}
\hline Tissue conditioning \\
\hline Surgical delay \\
Ischemic preconditioning \\
Remote ischemic preconditioning \\
Thermic preconditioning \\
Growth factors \\
Extracorporeal shock waves \\
Stemm cells \\
Pharmaceutical preconditioning \\
\hline
\end{tabular}

\section{Surgical delay}

Surgical delay is the predecessor of modern preconditioning techniques. By raising the flap itself without severing its pedicle, the vessels along the axis of the flap reorganize and increase in size, leading to a better perfusion of the distal flap due to a dilation of linking and choke vessels, causing a connection of adjacent vascular territories which could be demonstrated in animal models as well as in humans ${ }^{[31,32]}$. Direct linking vessels have a large caliber and connect adjacent vascular territories by connecting perforators themselves, while indirect linking vessels, also known as choke vessels, connect vascular territories via recurrent flow through the subdermal plexus ${ }^{[33,34]}$. The mechanisms behind this are still not fully understood but there are many animal studies that could show neovascularisation, vasodilation and reorganization of vessels due to surgical delay ${ }^{[35-37]}$. Although surgical delay proved to increase flap perfusion and therefore increased the survival of flaps in the clinical setting ${ }^{[38,39]}$, there are also major disadvantages to this strategy, especially the need for additional surgery and its risks for the affected patients as well as increased health care costs due to longer hospital stays. Especially in TRAM flaps surgical delay was used but due to the improvement of microsurgical methods free flaps as the DIEP flap have become a safer and more often applied alternative with less donor side morbidity ${ }^{[40-42]}$.

\section{Ischemic preconditioning}

Ischemic preconditioning was introduced by Mounsey et al ${ }^{[43]}$ for conditioning of the myocardium, but has since been applied to different fields of surgery including flap surgery. Murry et al. ${ }^{[4]}$ and Jennings et al. ${ }^{[45]}$ found that brief, intermittent cycles of ischemia have a protective effect on the myocardium resulting in a delay or even protection of lethal injury to the myocardial cells due to metabolic changes in the affected cells in a dog model. Various animal studies showed, that ischemic preconditioning leads to an increase in capillary perfusion, the vascular response to changes in perfusion pressure, a decrease in leukocytemediated reperfusion injury, an increase of critical ischemia time tolerated by the affected tissue, a decrease of vasospasms as well as a decrease in the capillary no-reflow phenomenon ${ }^{[46-49]}$. All of these mechanisms lead to a significant decrease in flap necrosis in skin flaps as well as in muscle flaps ${ }^{[48]}$. Because of these positive effects, the ideal application of ischemic preconditioning was examined as well. It was found that three cycles of ischemic preconditioning of $10 \mathrm{~min}$ each are superior to the application of only one or two cycles. They also found that a cycle of $10 \mathrm{~min}$ of ischemia is superior to $5 \mathrm{~min}$ of ischemia ${ }^{[50]}$. It could also be shown that there is no difference in the positive effect of ischemic preconditioning on reducing muscle flap necrosis whether it is applied $24 \mathrm{~h}$ or immediately before flap elevation ${ }^{[51]}$. Interestingly, ischemic preconditioning has immediate as well as late protective effects: the immediate effect is an improvement of the blood flow hemodynamics and an attenuation of the leukocyte-mediated reperfusion injury whereas after $24 \mathrm{~h}$ of reperfusion the improvement of the hemodynamics has subsided while the protective effect against reperfusion injury was still present ${ }^{[46]}$. Although there are those numerous positive effects of ischemic preconditioning it hasn't found its way into clinical routine use. The main reason for this might be the additional time needed for preparing the pedicle and applying ischemia prior to flap elevation as well as the spreading of new techniques like indocyanine 


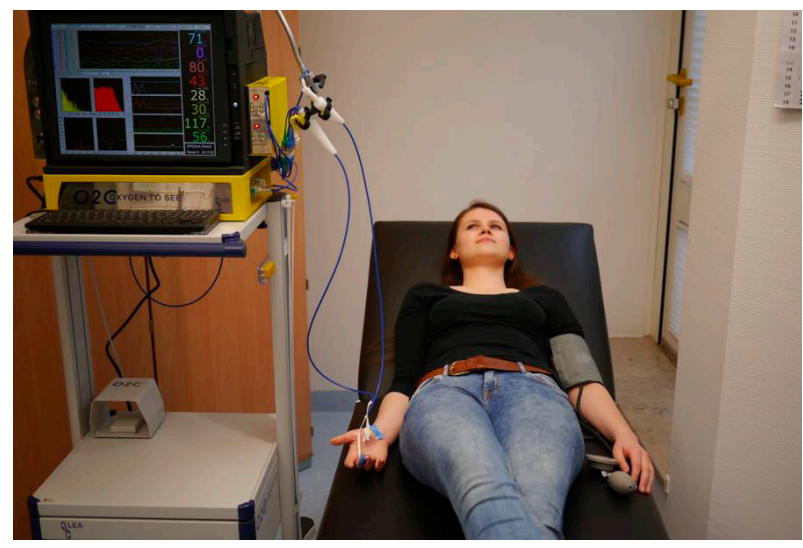

Figure 1. Remote ischemic conditioning: Examining the changes in tissue perfusion on the right hand of the test person after inducing ischemia on the left arm with a tourniquet

green (ICG) angiography, dynamic infrared thermography (DIRT), and photospectrometry which facilitate flap design ${ }^{[28,52,53]}$. One exception where ischemic preconditioning is routinely applied is the pedicled groin flap. It still poses as a viable option when free or local flaps cannot be used to reconstruct tissue defects ${ }^{[54]}$.

\section{Remote ischemic conditioning}

The idea of remote ischemic preconditioning was introduced by Przyklenk et al. ${ }^{[55]}$ in 1993 with their findings in a dog model that brief cycles of ischemia in a remote vascular bed are also capable of protecting myocardial cells from damage caused by the occlusion of coronary arteries. Plastic surgeons applied this idea to their line of work. Today three forms of remote ischemic conditioning exist: pre-, per-, and post-conditioning. In animal models it could be demonstrated that the induction of ischemia and reperfusion in a body part distant from the flap prior to its elevation could reduce the occurrence of flap necrosis in adipocutaneous flaps as well as in muscle flaps. They also found that ischemia and reperfusion could be induced non-invasively by the application of a tourniquet on a body area distant from the flap prior to flap elevation ${ }^{[6,57]}$. After those first promising results many experimental studies focused on the ideal type of application regarding remote ischemic conditioning. They found that inflating the tourniquet on the upper extremity had better effects on cutaneous microcirculation than on the lower extremity and that three circles of $10 \mathrm{~min}$ ischemia each were superior to shorter cycles or more frequent applications ${ }^{[58,59]}$ [Figure 1]. Those findings indicate that remote ischemic preconditioning has to be a systemic phenomenon but the mechanisms behind "classic" and remote ischemic conditioning are not yet fully understood. Various factors such as the release of nitric oxide, heatshock proteins, adenosine, ATP-sensitive K+ channels, cyclooxygenase as well as bradykinin through sensory nerve stimulation seem to be involved ${ }^{[60-66]}$. The protective effect of remote ischemic preconditioning against ischemia reperfusion-injury can be divided into two different timeframes. The acute effects last about four hours after the initial application of the preconditioning stimulus whereas the late effects occur after $24 \mathrm{~h}$ and last for at least another $24 \mathrm{~h}^{[67]}$. Furthermore the clinical application of remote ischemic conditioning is rather convenient as it is non-invasive and time-effective. The first study to examine remote ischemic conditioning in the clinical setting regarding flap surgery has shown promising results including an improvement of microcirculation in pedicled and free flaps ${ }^{[6]}$. Although there are many promising results regarding remote ischemic preconditioning there are also certain drawbacks. Some recent studies in the field of cardiac surgery revealed that the positive effects of remote ischemic preconditioning in laboratory studies may not be applied successfully in the clinical setting meaning there are no significant effects on the clinical outcome ${ }^{[69]}$.

\section{Thermic preconditioning}

Other research groups have focused on the protective effects of hypo- and hyperthermia concerning 
ischemic events and reperfusion-injury. By heating tissue to a temperature of $42{ }^{\circ} \mathrm{C}$ heat shock proteins (HSPs) are upregulated. HSP-70, HSP-72 and HSP-32 are reported to induce mechanisms which protect musculocutaneous, fasciocutaneous and skin flaps from ischemic injury if the hyperthermic preconditioning was conducted 6 to $24 \mathrm{~h}$ before flap elevation in animal studies ${ }^{[00-72]}$.

Hypothermia has protective effects caused by the downregulation of cellular metabolism as well as the induction of HSPs. Cooling the donor area $24 \mathrm{~h}$ before raising of the flap has shown to increase the expression of HSP-32 as well as significantly increase capillary perfusion and reduce skin flap necrosis in an experimental setting ${ }^{[73]}$.

\section{Other ways of tissue conditioning}

Pretreatment with growth factors which induce neovascularization has been investigated by some research groups. Until now, the application of vascular endothelial growth factor (VEGF) is the most widely investigated growth factor. The intravascular and subcutaneous application of VEGF proved to induce angiogenesis and increase flap survival in a rat model ${ }^{[74,75]}$. There has also been a gene therapeutic approach which showed a reduce of ischemic tissue in random skin flap models in rats by transfection with VEGF plasmids ${ }^{[76]}$. Other studies investigated the effects of human basic fibroblast growth factor (bFGF). Pretreatment with subcutaneous application of bEGF at the future donor site as well as the pretreatment of the recipient site of the flap via gene transfection showed an increase in vascularity and tissue perfusion in skin flap models in $\operatorname{rats}^{[77,78]}$.

Other research groups have focused on the effects of extracorporeal shock wave application (ESWA) on angiogenesis and tissue perfusion. Through ESWA, an increase in blood flow and angiogenesis as well as an improvement in tissue metabolism could be achieved in a mouse model ${ }^{[79-81]}$. In a rat model it could even be found that preoperative ESWA has a similar effect as surgical delay regarding microvessel density and perfusion, being non-invasive and easily applicable ${ }^{[82]}$. ESWA even decreases inflammatory reactions and therefore has a protective effect against reperfusion-injury ${ }^{[83]}$.

A further approach is the use of stem cells in tissue conditioning. In an experimental setting with Lewis rats it could be demonstrated that the venous application of adipose derived stem cells during reperfusion after an ischemic event could reduce necrosis in skin flaps and local application of adipose derived stem cells to the wound bed before suturing the flap could increase tissue perfusion and skin flap survival ${ }^{[84,85]}$.

Another means for tissue preconditioning is a pharmaceutical approach. Possible drugs should counteract the pathophysiological processes responsible for ischemia or ischemia reperfusion-injury. Of interest are drugs which improve microcirculation as heparin, drugs which cause vasodilation like beta-mimetics, selective calcium channel blockers and nitric oxide donors or drugs with anti-inflammatory effects like prostaglandinanalogues or cyclooxygenase inhibitors as could be shown in different animal models ${ }^{[86-91]}$.

\section{Tissue conditioning and wound healing}

Many of the above mentioned approaches in tissue conditioning are not only promising in plastic surgery but also seem to be an option for the improvement of wound healing, especially in wounds which are difficult to treat due to their size or the patients comorbidities and the resulting physiological changes in the tissue. For example there are many clinical studies investigating the positive effects of platelet rich plasma (PRP) on wounds, as it contains a large amount of cytokines, growth factors and chemokines ${ }^{[92,93]}$. Another, yet mainly experimental approach is the use of hypoxia to induce angiogenesis and improve wound healing. Therapeutic aspects using hypoxia include preconditioning cells in vitro or inducing hypoxia-mediated pathways in vivo by gene therapy or pharmaceutical agents, which eventually leads to an increase in pro-angiogenic growth 
factors and other angiogenic mediators in the wound bed ${ }^{[94]}$. Remote ischemic conditioning for example has also proven to be of use in diabetic patients. There are clinical studies that could show a significantly improved healing of diabetic foot ulcers due to remote ischemic conditioning ${ }^{[95,96]}$. And the effects of extracorporeal shock waves have been investigated in the clinical setting in burn patients as well. Researchers could show better results in terms of wound healing because of its positive effects on angiogenesis ${ }^{[79,80,97]}$.

\section{CONCLUSION}

Despite all the progress made in plastic and especially flap surgery, total or partial flap loss caused by ischemia or ischemia reperfusion-injury is still feared and has common complications. As temporary ischemia is inevitable in free flaps and the tissue of pedicled flaps is initially exposed to changes in perfusion as well, strategies to improve tissue viability are of vital importance. Many of the above mentioned, promising ways of tissue conditioning have yet only been tested under laboratory conditions or in animal models so further studies including clinical trials are needed. Those findings could not only offer great benefits in plastic surgery but in other fields of medicine as well, including the treatment of extensive or chronic wounds as well as transplant surgery. To lean on the words of Gillies ${ }^{[17]}$, tissue conditioning harbors the possibility to be an important weapon in the battle between beauty and blood supply.

\section{DECLARATIONS}

\section{Authors' contributions}

Designed and wrote the article, performed literature research and produced the figures: Krauss $S$

Assisted in designing the article, offered ideas concerning content of the article, corrected the article and proofread the final version: Kolbenschlag J

Read, corrected the article and discussed the content: Rothenberger J, Mayer J, Sogorski A, Held M, Wahler T, Daigeler A

\section{Availability of data and materials}

Not applicable.

\section{Financial support and sponsorship}

None.

\section{Conflicts of interest}

All authors declared that there are no conflicts of interest.

\section{Ethical approval and consent to participate}

Not applicable.

\section{Consent for publication}

Consent for publication was obtained.

\section{Copyright}

(c) The Author(s) 2018.

\section{REFERENCES}

1. Taeger CD, Müller-Seubert W, Horch RE, Präbst K, Münch F, Geppert CI, Birkholz T, Dragu A. Ischaemia-related cell damage in extracorporeal preserved tissue - new findings with a novel perfusion model. J Cell Mol Med 2014;18:885-94.

2. Messner F, Grahammer J, Hautz T, Brandacher G, Schneeberger S. Ischemia/reperfusion injury in vascularized tissue allotransplantation: tissue damage and clinical relevance. Curr Opin Organ Transplant 2016;21:503-9.

3. Petruzzo P, Lanzetta M, Dubernard JM, Landin L, Cavadas P, Margreiter R, Schneeberger S, Breidenbach W, Kaufman C, Jablecki J, 
Schuind F, Dumontier C. The international registry on hand and composite tissue transplantation. Transplantation 2010;90:1590-4.

4. Khalifian S, Cooney DS, Lee W, Brandacher G. The role of ischemia-reperfusion injury in reconstructive transplantation. J Transplant Technol Res 2013;004:3-004.

5. Soneja A, Drews M, Malinski T. Role of nitric oxide, nitroxidative and oxidative stress in wound healing. Pharmacol Rep 2005;57 Suppl:108-19.

6. Sen CK. The general case for redox control of wound repair. Wound Repair Regen 2003;11:431-8.

7. Schreml S, Szeimies RM, Prantl L, Karrer S, Landthaler M, Babilas P. Oxygen in acute and chronic wound healing. Br J Dermatol 2010;163:257-68.

8. Sheffield P. Tissue oxygen measurements. In: JC Davis TH, editor. Problem wounds: the role of oxygen. New York: Elsevier; 1988. p. $17-52$.

9. Khouri RK, Cooley BC, Kunselman AR, Landis JR, Yeramian P, Ingram D, Natarajan N, Benes CO, Wallemark C. A prospective study of microvascular free-flap surgery and outcome. Plastic and reconstructive surgery. Plast Reconstr Surg 1998;102:711-21.

10. Nahabedian MY, Momen B, Manson PN. Factors associated with anastomotic failure after microvascular reconstruction of the breast. Plast Reconstr Surg 2004;114:74-82.

11. Fischer JP, Wink JD, Nelson JA, Cleveland E, Grover R, Wu LC, Levin LS, Kovach SJ. A retrospective review of outcomes and flap selection in free tissue transfers for complex lower extremity reconstruction. J Reconstr Microsurg 2013;29:407-16.

12. Corbitt C, Skoracki RJ, Yu P, Hanasono MM. Free flap failure in head and neck reconstruction. Head Neck 2014;36:1440-5.

13. Banic A, Boeckx W, Greulich M, Guelickx P, Marchi A, Rigotti G, Tschopp H. Late results of breast reconstruction with free TRAM flaps: a prospective multicentric study. Plast Reconstr Surg 1995;95:1195-204; discussion 1205-6.

14. Wei FC, Celik N, Chen HC, Cheng MH, Huang WC. Combined anterolateral thigh flap and vascularized fibula osteoseptocutaneous flap in reconstruction of extensive composite mandibular defects. Plast Reconstr Surg 2002;109:45-52.

15. Tanaka N, Yamaguchi A, Ogi K, Kohama G. Sternocleidomastoid myocutaneous flap for intraoral reconstruction after resection of oral squamous cell carcinoma. J Oral Maxillofac Surg 2003;61:1179-83.

16. Moran SL, Serletti JM. Outcome comparison between free and pedicled TRAM flap breast reconstruction in the obese patient. Plast Reconstr Surg 2001;108:1954-60; discussion 1961-2.

17. Gillies H. Principles and art of plastic surgery: Lippincott Williams and Wilkins. New edition.1986.

18. Ibáñez B, Heusch G, Ovize M, Van de Werf F. Evolving therapies for myocardial ischemia/reperfusion injury. J Am Coll Cardiol 2015;65:1454-71.

19. Michiels C. Physiological and pathological responses to hypoxia. Am J Pathol 2004;164:1875-82.

20. Menger MD, Vollmar B. Pathomechanisms of ischemia-reperfusion injury as the basis for novel preventive strategies: is it time for the introduction of pleiotropic compounds? Transplant Proc 2007;39:485-8.

21. Eppihimer MJ, Granger DN. Ischemia/reperfusion-induced leukocyte-endothelial interactions in postcapillary venules. Shock 1997;8:1625.

22. Manson PN, Anthenelli RM, Im MJ, Bulkley GB, Hoopes JE. The role of oxygen-free radicals in ischemic tissue injury in island skin flaps. Ann Surg 1983;198:87-90.

23. Harlan JM, Killen PD, Harker LA, Striker GE, Wright DG. Neutrophil-mediated endothelial injury in vitro mechanisms of cell detachment. J Clin Invest 1981;68:1394-403.

24. Sacks T, Moldow CF, Craddock PR, Bowers TK, Jacob HS. Oxygen radicals mediate endothelial cell damage by complement-stimulated granulocytes. An in vitro model of immune vascular damage. J Clin Invest 1978;61:1161-7.

25. Küntscher MV, Hartmann B, Germann G. Remote ischemic preconditioning of flaps: a review. Microsurgery 2005;25:346-52.

26. Pang CY, Yang RZ, Neligan P, Xu N, Chiu C, Zhong A, Forrest CR. Vascular effects and mechanism of action of endothelin-1 in isolated perfused pig skin. J Appl Physiol (1985). 1995;79:2106-13.

27. Im MJ, Manson PN, Bulkley GB, Hoopes JE. Effects of superoxide dismutase and allopurinol on the survival of acute island skin flaps. Ann Surg 1985;201:357-9.

28. Harder Y, Amon M, Laschke MW, Schramm R, Rücker M, Wettstein R, Bastiaanse J, Frick A, Machens HG, Küntscher M, Germann G, Vollmar B, Erni D, Menger MD. An old dream revitalised: preconditioning strategies to protect surgical flaps from critical ischaemia and ischaemia-reperfusion injury. J Plast Reconstr Aesthet Surg 2008;61:503-11.

29. Menger MD, Laschke MW, Amon M, Schramm R, Thorlacius H, Rücker M, Vollmar B. Experimental models to study microcirculatory dysfunction in muscle ischemia-reperfusion and osteomyocutaneous flap transfer. Langenbecks Arch Surg 2003;388:281-90.

30. Menger MD, Rücker M, Vollmar B. Capillary dysfunction in striated muscle ischemia/reperfusion: on the mechanisms of capillary "noreflow". Shock 1997;8:2-7.

31. Callegari PR, Taylor GI, Caddy CM, Minabe T. An anatomic review of the delay phenomenon: I. experimental studies. Plast Reconstr Surg 1992;89:397-407; discussion 417-8.

32. Taylor GI, Corlett RJ, Caddy CM, Zelt RG. An anatomic review of the delay phenomenon: II. clinical applications. Plast Reconstr Surg 1992;89:408-16; discussion 17-8.

33. Saint-Cyr M, Wong C, Schaverien M, Mojallal A, Rohrich RJ. The perforasome theory: vascular anatomy and clinical implications. Plast Reconstr Surg 2009;124:1529-44.

34. Taylor GI, Corlett RJ, Dhar SC, Ashton MW. The anatomical (angiosome) and clinical territories of cutaneous perforating arteries: development of the concept and designing safe flaps. Plast Reconstr Surg 2011;127:1447-59.

35. Jonsson K, Hunt TK, Brennan SS, Mathes SJ. Tissue oxygen measurements in delayed skin flaps: a reconsideration of the mechanisms of the delay phenomenon. Plast Reconstr Surg 1988;82:328-36.

36. Morris SF, Yang D. Effect of vascular delay on viability, vasculature, and perfusion of muscle flaps in the rabbit. Plast Reconstr Surg 
1999;104:1041-7.

37. Mcfarlane RM, Heagy FC, Radin S, Aust JC, Wermuth RE. A study of the delay phenomenon in experimental pedicle flaps. Plast Reconstr Surg 1965;35:245-62.

38. Restifo RJ, Ward BA, Scoutt LM, Brown JM, Taylor KJ. Timing, magnitude, and utility of surgical delay in the TRAM flap: II. clinical studies. Plast Reconstr Surg 1997;99:1217-23.

39. Scheufler O, Andresen R, Kirsch A, Banzer D, Vaubel E. Clinical results of TRAM flap delay by selective embolization of the deep inferior epigastric arteries. Plast Reconstr Surg 2000;105:1320-9.

40. Codner MA, Bostwick J, 3rd. The delayed TRAM flap. Clin Plast Surg 1998;25:183-9.

41. Erdmann D, Sundin BM, Moquin KJ, Young H, Georgiade GS. Delay in unipedicled TRAM flap reconstruction of the breast: a review of 76 consecutive cases. Plast Reconstr Surg 2002;110:762-7.

42. Momoh AO, Colakoglu S, Westvik TS, Curtis MS, Yueh JH, de Blacam C, Tobias AM, Lee BT. Analysis of complications and patient satisfaction in pedicled transverse rectus abdominis myocutaneous and deep inferior epigastric perforator flap breast reconstruction. Ann Plast Surg 2012;69:19-23.

43. Mounsey RA, Pang CY, Boyd JB, Forrest C. Augmentation of skeletal muscle survival in the latissimus dorsi porcine model using acute ischemic preconditioning. T J Otolaryngol 1992;21:315-20.

44. Murry CE, Jennings RB, Reimer KA. Preconditioning with ischemia: a delay of lethal cell injury in ischemic myocardium. Circulation 1986;74:1124-36.

45. Jennings RB, Murry CE, Reimer KA. Preconditioning myocardium with ischemia. Cardiovasc Drugs Ther 1991;5:933-8.

46. Adanali G, Ozer K, Siemionow M. Early and late effects of ischemic preconditioning on microcirculation of skeletal muscle flaps. Plast Reconstr Surg 2002;109:1344-51.

47. Kinnunen I, Laurikainen E, Schrey A, Laippala P, Aitasalo K. Effect of acute ischemic preconditioning on blood-flow response in the epigastric pedicled rat flap. J Reconstr Microsurg 2002;18:61-8.

48. Zahir KS, Syed SA, Zink JR, Restifo RJ, Thomson JG. Ischemic preconditioning improves the survival of skin and myocutaneous flaps in a rat model. Plast Reconstr Surg 1998;102:140-50; discussion 151-2.

49. Wang WZ, Anderson G, Maldonado C, Barker J. Attenuation of vasospasm and capillary no-reflow by ischemic preconditioning in skeletal muscle. Microsurgery 1996;17:324-9.

50. Zahir TM, Zahir KS, Syed SA, Restifo RJ, Thomson JG. Ischemic preconditioning of musculocutaneous flaps: effects of ischemia cycle length and number of cycles. Ann Plast Surg 1998;40:430-5.

51. Carroll CM, Carroll SM, Overgoor ML, Tobin G, Barker JH. Acute ischemic preconditioning of skeletal muscle prior to flap elevation augments muscle-flap survival. Plast Reconstr Surg 1997;100:58-65.

52. Lohman RF, Ozturk CN, Ozturk C, Jayaprakash V, Djohan R. An analysis of current techniques used for intraoperative flap evaluation. Ann Plast Surg 2015;75:679-85.

53. Ludolph I, Arkudas A, Schmitz M, Boos AM, Taeger CD, Rother U, Horch RE, Beier JP. Cracking the perfusion code? Laser-assisted indocyanine green angiography and combined laser doppler spectrophotometry for intraoperative evaluation of tissue perfusion in autologous breast reconstruction with DIEP or ms-TRAM flaps. J Plast Reconstr Aesthet Surg 2016;69:1382-8.

54. Goertz O, Kapalschinski N, Daigeler A, Hirsch T, Homann HH, Steinstraesser L, Lehnhardt M, Steinau HU. The effectiveness of pedicled groin flaps in the treatment of hand defects: results of 49 patients. J Hand Surg Am 2012;37:2088-94.

55. Przyklenk K, Bauer B, Ovize M, Kloner RA, Whittaker P. Regional ischemic 'preconditioning' protects remote virgin myocardium from subsequent sustained coronary occlusion. Circulation 1993;87:893-9.

56. Küntscher MV, Schirmbeck EU, Menke H, Klar E, Gebhard MM, Germann G. Ischemic preconditioning by brief extremity ischemia before flap ischemia in a rat model. Plast Reconstr Surg 2002;109:2398-404.

57. Küntscher MV, Kastell T, Sauerbier M, Nobiling R, Gebhard MM, Germann G. Acute remote ischemic preconditioning on a rat cremasteric muscle flap model. Microsurgery 2002;22:221-6.

58. Kolbenschlag J, Sogorski A, Harati K, Daigeler A, Wiebalck A, Lehnhardt M, Kapalschinski N, Goertz O. Upper extremity ischemia is superior to lower extremity ischemia for remote ischemic conditioning of antero-lateral thigh cutaneous blood flow. Microsurgery 2015;35:211-7.

59. Kolbenschlag J, Sogorski A, Timmermann C, Harati K, Daigeler A, Hirsch T, Goertz O, Lehnhardt M. Ten minutes of ischemia is superior to shorter intervals for the remote ischemic conditioning of human microcirculation. Clin Hemorheol Microcirc 2017;66:239-48.

60. Schoemaker RG, van Heijningen CL. Bradykinin mediates cardiac preconditioning at a distance. Am J Physiol Heart Circ Physiol 2000;278:H1571-6.

61. Nandagopal K, Dawson TM, Dawson VL. Critical role for nitric oxide signaling in cardiac and neuronal ischemic preconditioning and tolerance. J Pharmacol Exp Ther 2001;297:474-8.

62. Kume M, Yamamoto Y, Saad S, Gomi T, Kimoto S, Shimabukuro T, Yagi T, Nakagami M, Takada Y, Morimoto T, Yamaoka Y. Ischemic preconditioning of the liver in rats: implications of heat shock protein induction to increase tolerance of ischemia-reperfusion injury. J Lab Clin Med 1996;128:251-8.

63. Pang CY, Neligan P, Zhong A, He W, Xu H, Forrest CR. Effector mechanism of adenosine in acute ischemic preconditioning of skeletal muscle against infarction. Am J Physiol 1997 ;273:R887-95.

64. Pang CY, Neligan P, Xu H, He W, Zhong A, Hopper R, Forrest CR. Role of ATP-sensitive K+ channels in ischemic preconditioning of skeletal muscle against infarction. T Am J Physiol 1997;273:H44-51.

65. Guo Y, Bao W, Wu WJ, Shinmura K, Tang XL, Bolli R. Evidence for an essential role of cyclooxygenase-2 as a mediator of the late phase of ischemic preconditioning in mice. asic Res Cardiol 2000;95:479-84.

66. Sogorski A, Harati K, Kapalschinski N, Daigeler A, Hirsch T, Lehnhardt M, Goertz O, Kolbenschlag J. Remote ischemic conditioning - 
endogenous tissue protection and its possible applications in surgery. Zentralbl Chir 2018;143:42-9.

67. Loukogeorgakis SP, Panagiotidou AT, Broadhead MW, Donald A, Deanfield JE, MacAllister RJ. Remote ischemic preconditioning provides early and late protection against endothelial ischemia-reperfusion injury in humans: role of the autonomic nervous system. J Am Coll Cardiol 2005;46:450-6.

68. Kolbenschlag J, Sogorski A, Kapalschinski N, Harati K, Lehnhardt M, Daigeler A, Hirsch T, Goertz O. Remote ischemic conditioning improves blood flow and oxygen saturation in pedicled and free surgical flaps. Plast Reconstr Surg 2016;138:1089-97.

69. Meybohm P, Bein B, Brosteanu O, Cremer J, Gruenewald M, Stoppe C, Coburn M, Schaelte G, Böning A, Niemann B, Roesner J, Kletzin F, Strouhal U, Reyher C, Laufenberg-Feldmann R, Ferner M, Brandes IF, Bauer M, Stehr SN, Kortgen A, Wittmann M, Baumgarten G, Meyer-Treschan T, Kienbaum P, Heringlake M, Schön J, Sander M, Treskatsch S, Smul T, Wolwender E, Schilling T, Fuernau G, Hasenclever D, Zacharowski K; RIPHeart Study Collaborators. A multicenter trial of remote ischemic preconditioning for heart surgery. N Engl J Med 2015;373:1397-407.

70. Wang BH, Ye C, Stagg CA, Lin M, Fawcett T, VanderKolk CA, Udelsman R. Improved free musculocutaneous flap survival with induction of heat shock protein. Plast Reconstr Surg 1998;101:776-84.

71. Harder Y, Contaldo C, Klenk J, Banic A, Jakob SM, Erni D. Improved skin flap survival after local heat preconditioning in pigs. J Surg Res 2004;119:100-5.

72. Harder Y, Amon M, Schramm R, Georgi M, Banic A, Erni D, Menger MD. Heat shock preconditioning reduces ischemic tissue necrosis by heat shock protein (HSP)-32-mediated improvement of the microcirculation rather than induction of ischemic tolerance. Ann Surg 2005;242:869-78; discussion 878-9.

73. Kubulus D, Amon M, Roesken F, Rücker M, Bauer I, Menger MD. Experimental cooling-induced preconditioning attenuates skin flap failure. Br J Surg 2005;92:1432-8.

74. Zhang F, Fischer K, Komorowska-Timek E, Guo M, Cui D, Dorsett-Martin W, Buncke HJ, Lineaweaver WC. Improvement of skin paddle survival by application of vascular endothelial growth factor in a rat TRAM flap model. Ann Plast Surg 2001;46:314-9.

75. Padubidri A, Browne E Jr. Effect of vascular endothelial growth factor (VEGF) on survival of random extension of axial pattern skin flaps in the rat. Ann Plast Surg 1996;37:604-11.

76. Basu G, Downey H, Guo S, Israel A, Asmar A, Hargrave B, Heller R. Prevention of distal flap necrosis in a rat random skin flap model by gene electro transfer delivering VEGF(165) plasmid. J Gene Med 2014;16:55-65.

77. Uhl E, Barker JH, Bondàr I, Galla TJ, Lehr HA, Messmer K. Improvement of skin flap perfusion by subdermal injection of recombinant human basic fibroblast growth factor. Ann Plast Surg 1994;32:361-5; discussion 365-6.

78. Fujihara Y, Koyama H, Nishiyama N, Eguchi T, Takato T. Gene transfer of bFGF to recipient bed improves survival of ischemic skin flap. Br J Plast Surg 2005;58:511-7.

79. Goertz O, Hauser J, Hirsch T, von der Lohe L, Kolbenschlag J, Stricker I, Lehnhardt M, Lauer H. Short-term effects of extracorporeal shock waves on microcirculation. J Surg Res 2015;194:304-11.

80. Goertz O, Lauer H, Hirsch T, Ring A, Lehnhardt M, Langer S, Steinau HU, Hauser J. Extracorporeal shock waves improve angiogenesis after full thickness burn. Burns 2012;38:1010-8.

81. Goertz O, von der Lohe L, Lauer H, Khosrawipour T, Ring A, Daigeler A, Lehnhardt M, Kolbenschlag J. Repetitive extracorporeal shock wave applications are superior in inducing angiogenesis after full thickness burn compared to single application. Burns 2014;40:1365-74.

82. Reichenberger MA, Keil H, Mueller W, Herold-Mende C, Gebhard MM, Germann G, Engel H. Comparison of extracorporal shock wave pretreatment to classic surgical delay in a random pattern skin flap model. Plast Reconstr Surg 2011;127:1830-7.

83. Reichenberger MA, Heimer S, Schaefer A, Lass U, Gebhard MM, Germann G, Engel H, Köllensperger E, Leimer U, Mueller W. Extracorporeal shock wave treatment protects skin flaps against ischemia-reperfusion injury. Injury 2012;43:374-80.

84. Reichenberger MA, Heimer S, Schaefer A, Lass U, Gebhard MM, Germann G, Leimer U, Köllensperger E, Mueller W. Adipose derived stem cells protect skin flaps against ischemia-reperfusion injury. Stem Cell Rev 2012;8:854-62.

85. Reichenberger MA, Mueller W, Schäfer A, Heimer S, Leimer U, Lass U, Germann G, Köllensperger E. Fibrin-embedded adipose derived stem cells enhance skin flap survival. Stem Cell Rev 2012;8:844-53.

86. Barker JH, Hammersen F, Galla TJ, Bondàr I, Zeller P, Menger MD, Messmer K. Direct monitoring of capillary perfusion following normovolemic hemodilution in an experimental skin-flap model. Plast Reconstr Surg 1990;86:946-54.

87. Miyawaki T, Jackson IT, Elmazar H, Bier UC, Barakat K, Andrus L, Williams F. The effect of low-molecular-weight heparin in the survival of a rabbit congested skin flap. Plast Reconstr Surg 2002;109:1994-9.

88. Finseth F, Zimmermann J. Prevention of necrosis in island myocutaneous flaps in the pig by treatment with isoxsuprine. Plast Reconstr Surg 1979;64:536-9.

89. Stein HJ, Fayman MS, Oosthuizen MM, Hinder RA. Verapamil improves survival of rat hyperemic island skin flaps. Surgery 1989;106:61722; discussion 622-3.

90. Küntscher MV, Juran S, Menke H, Gebhard MM, Erdmann D, Germann G. The role of pre-ischaemic application of the nitric oxide donor spermine/nitric oxide complex in enhancing flap survival in a rat model. Br J Plast Surg 2002;55:430-3.

91. Salerno GM, McBride DM, Bleicher JN, Watson P, Stromberg BV. Ciprostene and indomethacin partially reverse the mechanisms of distal end necrosis in the rat random skin flap. Ann Plast Surg 1992;28:526-33; discussion 534.

92. Frykberg RG, Driver VR, Carman D, Lucero B, Borris-Hale C, Fylling CP, Rappl LM, Clausen PA. Chronic wounds treated with a physiologically relevant concentration of platelet-rich plasma gel: a prospective case series. Ostomy Wound Manage 2010;56:36-44.

93. Carter MJ, Fylling CP, Parnell LK. Use of platelet rich plasma gel on wound healing: a systematic review and meta-analysis. Eplasty 2011;11:e38.

94. Hadjipanayi E, Schilling AF. Hypoxia-based strategies for angiogenic induction: the dawn of a new era for ischemia therapy and tissue regeneration. Organogenesis 2013;9:261-72. 
95. Shaked G, Czeiger D, Abu Arar A, Katz T, Harman-Boehm I, Sebbag G. Intermittent cycles of remote ischemic preconditioning augment diabetic foot ulcer healing. Wound Repair Regen 2015;23:191-6.

96. Boghossian JA, Joseph B, Slepian MJ, Armstrong DG. Remote ischemic conditioningpromising potential in wound repair in diabetes? J Am Podiatr Med Assoc 2017;107:313-7.

97. Arnó A, García O, Hernán I, Sancho J, Acosta A, Barret JP. Extracorporeal shock waves, a new non-surgical method to treat severe burns. Burns 2010;36:844-9. 